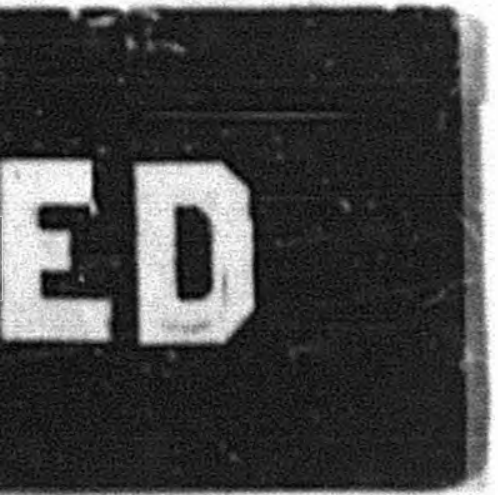

\title{
hade 1714
}

AECD 3636

LOB ALANOS BC Trartric LABORATORY no. 44593

of the

UNIVERSTTY OF CALIPORNIA

ORIEMEED DIOXIDE FILWB OH URANIUA

Reference: CIR-5-2037

July 6, 2954

By: J. T. Waber

J. A. O'Rourke

CUSSIMTOAPIOH CAIOELLD

Mren-2-2-2-54

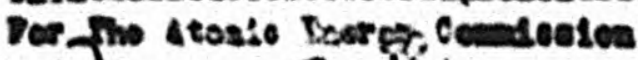

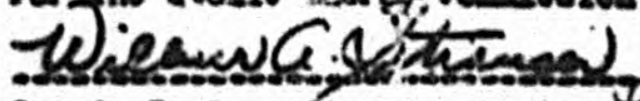

Chios, Doolacelf ivation. Franed \&

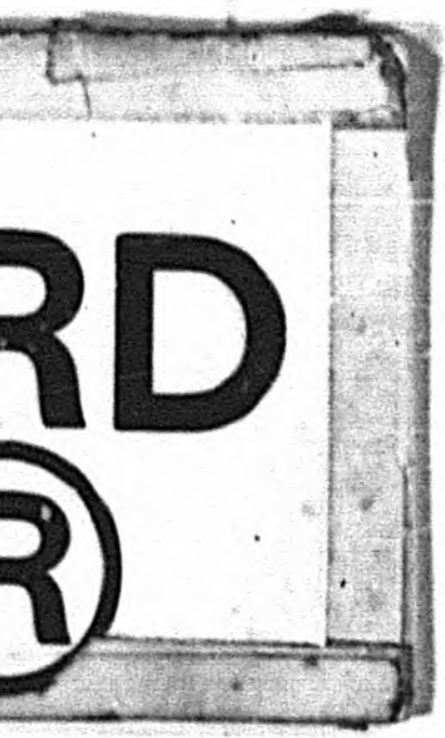


Th1s phenonenological report deals with the formation of orlented layere of an oxide vhich form during oxidation vithout any evident relationship to the parent and under2ying metal. It $1 \mathrm{~s}$ offered vithout explanetion or proposed mechaniem.

In generel, orlentation of depoeltod files occurs when the supereaturation, 1.e., the driving force, is too omall to permit easy and frequent homogeneous nucleation. Then the films take on a grovth hablt characteristic elther of the substrate or of their own dielocations. If the supersaturation in the vicinfty of the interface 18 blgh enough, homogeneous or self-nucleation occurs and randomly oriented films occur. A common technique for obtalning oriented motal f1lms by vepor deposition is to add an Inert gas to the vapor and thus effectively lover the supersaturation at the interface by reducing the rate of arrival of vapor. Similarly, the techn1que for discouraging dendritic (orlented) growth during electrodeposition of a metal is to establish a large reservoir of the cation in the vicinity of the Interface as a complex 1on and by using hlgh current densities; that 1s, by Increasing the local supersetureaturation, to stimulate nucleation.

It 18, therefore, somevbat surprioling that the present phenosenon occure at high gas pressures and less effectively at $10 \mathrm{w}$.

Specifically, the reaction studied is the formation of uranium dioxide at Beveral hundred degrees centigrade by relatively low pressures of vater vapor. Conventional X-ray techniques vere used principally for etudying this reaction and examination vas done at room temperatures. Stereographic projections 
establish that the texture of the oriented oxide is alsost exclusively the following: The (110) planes of the eluorite lattice of $\mathrm{VO}_{2}$ are parallel to the metal ourfece. As background, it should be eaphasized that an oriented oxide has not been eeen on even oingle crystals of uranium except undor the experimental conditions to be described below.

It vas possible to form a different orientation of the $\mathrm{NO}_{2} \mathrm{fl}=$ in vacuum. Three different cryetal structures of the metal could be obtained by changing the temperature but these apparently different oubstrates ald not affect the resulting (100) f1ber-l1ke texture of the oxide. Starting vith this $(100)$ texture, the specimens formed the (210) texture when oxidized In vater vapor. Therefore, the latter texture vhich we are reporting, does not grow in ep1taxial relation to the dloxide already present.

Nahl and McCandlese ${ }^{1}$ have described the co.altions under which orlented PeO Plime form on ferrite crystals and have Indicated that the addition of hydrogen to thp vater vapor is nacessary. Gulbransen ${ }^{2}$ has confirnod this observation. This experience is reminiecent of the addition of argon or sir dur1ng vapor doposition. Nehl and Iustan ${ }^{3}$ bave observed that $\mathrm{Cu}_{2} \mathrm{O}$ is oriented when formed on single cryetal of copper.

One cannot establish that a stagnant layer of hydrogen formed by reaction of the vater does not Insulate the uraniun-oxide surfece froa further rapid attack. Iix the few experiments where hydrogen vas added to the vater vapor, - significant effect on orientation vas not noted. Further, the degree or orientstion fincreases as the pressure of vater vapor 1ncreases. Thus in these eeveral features the phonowenon appears to be unlike the formation of orlented P1ins previously reported. 


\section{Pertinent Cryatal structurea}

At $668^{\circ} \mathrm{C}$, vith inereasing temperature, the orthorhomble alpha phase changes to a complex tetragonal phase 5 . At $774^{\circ} \mathrm{C}$, the latter changes to the body-centered cuble phase ${ }^{4}$ valch is then otable up to the melting point ${ }^{6}$ at $1125^{\circ} \mathrm{C}$. An excellent aumary of the physical and chemicel proportiea of uraniua wetal bas been publiehed recently 6 .

Uranlua monoxide has the NaCl structure v1th $a_{0}-4.938$ and the dioxide bas the $\mathrm{CaP}_{2}$ otructure with $\mathrm{e}_{0}=5.4581$ \&. Varlation of these lattice paramoters with composition has been oumarized by Katz and Rabinoultch ${ }^{7}$.

\section{Experimental' Conditione}

Both mechanically pollohed and electropolished as-rolled motal specinens were used. The specimeno vere outgassed at rocm temperature in the equipant for several hours in a $10^{-5^{\circ}} \mathrm{m}$ Ig or better vacuum. Then the allica furnace tube containing the specimen vas heated to the test temperature vhich lay in the range of 300 to $1000^{\circ} \mathrm{C}$. Droplets of vater vere introduced into the evacuated system through a Hg covered fine-pore sintered glase frit. The vapor proseure did not exceed the condeneation pressure of water on the parts of the oystem which vere at room temperature and thus ve vere $11 \mathrm{mit}$ tod to vater pressures below about $25 \mathrm{~m}$ Hg. The teat pressure was deteralned after the vater vapor had been expanded from the measuring part of the oystem into the hot furnace tube.

The texture of the cold-rolled netal was determined on a number of specinens prior to test. S1nce the several textures observed do not appear to influence the texture of the oxide, the detalled metal orlentation will not be discussed here. The textures of the metal and of the oxide film were determined with the ald of a schultz orlentation gonlometer ${ }^{8}$ adaptod for use on a Norelco Type 7 ( ( ) X-ray diffraction un1t. 
As a prelistnary 10dication of the degree of orientation in the oxide the intenalty of the (111), (200) and (220) lines of the oxide f1la vere deternined vith a Ceneral Electric XRD-5 X-ray diffraction unit.

A preciolion and rinosese of teaperature control in the rurnace vas tolerated vhlch vae poorer than would be acceptable in a kinetic etudy. Inasmuch as the oxide shows the sase orientation behavior at $300^{\circ} \mathrm{C}$ so it does at $600^{\circ} \mathrm{C}$, the observed temperature variations of $\pm 20^{\circ} \mathrm{C}$ probably do not have ignificant erfect on the mechanlem.

\section{Experimental Reaulte}

The principal features of the results obtained to cate are; (1) the effect of temperature and preseure, (2) effect of preformad nonoxide and aloxide f1Ime and (3) a preliminary Investigation of tha rato lav.

Most of thie orientation vill be indicatod below in terms of the ratio of Intensity of the (220) reflectlons of $\mathrm{vO}_{2}$ to the Intensity of the (212) reflections. A recent Bureau of Standardo publicat1on ${ }^{9}$ reports thls ratio to be 0.49 for a randon pouder seaple. When the (110) planes are perpendicular or parallel to the opecimen eurface, th10 rat10 vill be grester than 0.49 . Values as h1gh as 35 have been observed.

In order to establioh vhat orientation was present and responsible for the high rat10, standard stereographic projections and pole f1gures vere constructed and the identification of the texture vas from these using Whase nots. The reader 18 referred to a standard text ${ }^{20}$ for detallo on understanding, constructing and Interpreting pole f1gures.

\section{Effect of Water Pressure and Temperature}

There Is apparently a minimen preseure of water vapor below vhlch the 
degree of orientation is suals and above vhich the orlentation is atrongly developed. This critical preasure is poorly defined by our preliminary experinents. The results, which pertain to the formation of oxide in the alpha range of stability, are presented in rable I.

\section{TABLS I}

Orientation Pat10 $\mathrm{I}(220) / \mathrm{I}(110)$ for Alpha Uranium

Tempereture $\left({ }^{\circ} \mathrm{C}\right)$ Pressure (m)

Rat1o

200

0.2

0.48

300

1.3

4.2

11.6

400

500

600

0.8

5.0

12.2
5.6

4.7

$4.3,5.1$

0.33

5.6

5.4

$18.2,35.0$

$2.4,6.4$

22.10

vacuum

0.31

1.0

12.2

11.4

0.5

4.0

5.2

6.2

-Conducted with reorlented sections of rolled metal.

Whether the critical 11mit of vater 10 affected by temperature cannot be established with these linited dats. However, it is clear that high degrees of orlentation are formed, as evidenced by this ratio of intensities, when the water pressure exseeds about 0.8 of mercury. Above th1s "critical pressure" the preseure dependence of orlentation 1s very amall. 


\section{Orientation of D10xide F1]ms Formed in Vacuo}

One must digrese from the maln 21 ne of discussion to present some data which show that a $(100)$ texture of the dloxide forns in good vacua. Thls bobavior of uranium is important since filmo containing a different orlentation can subeequently be oxidized in vater vepor.

Experiments were carried out in vacua of $10^{-5}=$ or better and at 400 , 600 and $1000^{\circ} \mathrm{C}$. In each of these cases, the principal orlentation of the dioxide is vith the $(100)$ planes parallel to the specimen ourface. Bowever, uranium monoxide is also present in all such films formod in vacuum and what restraint it 1 mposes on the texture of the doxide $1 \mathrm{~s}$ not known. The teat data are surmarlized in Table II-A.

TABLE II-A

Relative Intensity of Oxide X-ray Reflection

\begin{tabular}{|c|c|c|c|c|c|c|c|}
\hline $\begin{array}{l}\text { 8pecimen } \\
\text { number }\end{array}$ & (7gap. & $\begin{array}{l}\text { Duretion } \\
\text { (brs.) }\end{array}$ & ण Re: & $\frac{\text { Lat1 ve Int }}{\mathrm{UO}_{2}(\mathrm{II})}$ & $\frac{\text { ensity }}{\mathrm{UO}_{2}(200)}$ & ${ }^{00}{ }^{2}$ (ख्र) & $\underset{\text { Texture }}{\text { P1Im }}$ \\
\hline 2130 & 400 & $1-1 / 2$ at $10^{-5}$ & 20 & 25 & 160 & 25 & (100) vo, \\
\hline 1952 & 600 & $1 / 2$ at $10^{-6}$ & 170 & 50 & 150 & 19 & $(200) 00$ \\
\hline 2954 & 600 & $1 / 4$ at $10^{-6}$ & 70 & 20 & 75 & 7 & (100) 00 \\
\hline 1802 & 1000 & 19 at $10^{-5}$ & 210 & 32 & so & 29 & (100) vo, \\
\hline
\end{tabular}

The amounts of monoxide in the PIIms are indicated by the relative Intensities of the (211) IInes of the VO and $\mathrm{VO}_{2}$, Bince the scattering factor for this plane of the monoxide is 91 per cent of that for the dioxide. The observation that the (100) dioxide texture is formed in vacuo is better lemonstrated by comparing the tvo orientation ratios computed from Table II-A. These ratios are given in Table II-B. 


\section{- TABIB II-B}

Comparative Orientation Ratios for D1oxide F1Ims

Formed in Vacunim

Specimen

Ratio

Rat10

Mnumber

$I(200) / I(121)$

$I(220) / I(111)$

$\begin{array}{lll}2130 & 6.4 & 1.0 \\ 1952 & 3.0 & 0.4 \\ 1954 & 3.75 & 0.3 \\ 1802 & 1.56 & 0.6\end{array}$

The relative rat10 for Intensities $I(200)$ and $I(21)$ is randon powder samples of $\mathrm{VO}_{2}$ is 0.48 as reported by the Bureeu of Standards 9 . Although these orientation ratios by themeelves do not demonstrete that the (100) texture is present and only that the f1lmo are orlented, subeequent vork using stereographic projection have demonstrated that (200) texture is the correct orlentation. Th1s work vill be discussed later.

\section{Oxidation of Preforad P1lme}

Starting with a film with the (100) texture, 1t vas posolble to axidize the metal further in vater vapor and develop the (210) orlentation. Admittedily the texture vas more incoupletely formed when preforned layero were present.

As a basis for compar1son, a metal coupon was oxidized in vacuman at $600^{\circ} \mathrm{C}$ and examined by $X$-ray diffrection to establiah the nature of the f1lm. A mechanlcally pollebed coupon of the came rolled matal stock was pleced with the vacuum-treated opecimen in the furnace at $600^{\circ} \mathrm{C}$ and oxidized for one hour at a vater pressure of 0.3 . After $X$-ray examination, the two coupons were repleced in the furnace and oxid1zed at $600^{\circ} \mathrm{C}$ for one hour at a pressure of $6.2 \mathrm{~mm}$. The data in Table III 11lustrate the obeervation that the (110) texture, characteristic of vater vajor, v1ll develop $1 f$ eufficient vater is present. 
A simflar experiment vas conducted at $400^{\circ} \mathrm{C}$ and the pertinent dats are recorded in Table IV.

2ABLS III

Carparison of the Degree of Orlentation Formed on Oxidation of Preformed $\mathrm{F} 1 \mathrm{~lm}$ at $600^{\circ} \mathrm{C}$

\begin{tabular}{|c|c|c|c|}
\hline $\begin{array}{l}\text { Specimen } \\
\text { mumber }\end{array}$ & Treatment G1 ven & $\mathrm{I}(220) \frac{\text { Orlentation }}{\mathrm{I}\left(\mathbf{2}^{2} 0\right)^{\text {क }}}$ & $\begin{array}{l}\text { Rat10 } \\
I(220) / I(121)\end{array}$ \\
\hline $\begin{array}{l}1952 \\
1952\end{array}$ & $\begin{array}{l}\text { Vacuura, } 1 / 2 \mathrm{hr} \\
\text { Vecuum, I hr }\end{array}$ & $\begin{array}{l}0.25,0.09 \\
0.25,0.20\end{array}$ & $\begin{array}{l}2.6,3.8 \\
1.7,3.3\end{array}$ \\
\hline $\begin{array}{l}1952 \mathrm{a} \\
1952 b\end{array}$ & $\begin{array}{l}\text { Vecuum }+0.3 \mathrm{~mm} \\
\text { Vecuum }+0.3 \mathrm{~mm}+6.2 \mathrm{~m}\end{array}$ & $\begin{array}{l}0.23,0.30 \\
0.45,0.48\end{array}$ & $\begin{array}{l}2.0,2.5 \\
0.79,0.83\end{array}$ \\
\hline $\begin{array}{l}1966 \\
1966 a\end{array}$ & $\begin{array}{l}0.3= \\
0.3=+6.2=m\end{array}$ & $\begin{array}{l}0.74,0.89 \\
1.29,1.86\end{array}$ & $\begin{array}{l}5.4,4.0 \\
4.0,4.0\end{array}$ \\
\hline
\end{tabular}

-Values obtained parallel to the rolling direction given first.

* Random orlentation would give 1.02.

\section{TABLE IV}

Oxidation of Preforaed Film

at $400^{\circ} \mathrm{C}$

\begin{tabular}{lllccc}
$\begin{array}{l}\text { Speciman } \\
\text { Mumber }\end{array}$ & $\begin{array}{c}\text { Prellminary } \\
\text { Treatment }\end{array}$ & $\begin{array}{c}\text { Water } \\
\text { Pressure }(m)\end{array}$ & I(200) $\frac{\text { Orientation Ratios }}{\text { IIII) }}$ & I(220)/I(22I) \\
\hline 2130 & Electropolished & vacuium & 6.4 & 1.0 \\
2131 & Vac. Annealed & 28.4 & 0.3 & 1.0 \\
2132 & Electropollshed & 28.4 & 0.6 & 1.8
\end{tabular}

Tables III and IV indicate that the (110) texture is being produced at the expense of the $(100)$ texture initelly present.

The olgnificance of these data is that they denonstrate that the developsent of the (110) texture is not dependent upon the randomness or the previous orientation of any 111 m present. A logical explanation is that the 


\begin{abstract}
8
characterist1c vater texture is the result of competing grourth rates.

The data do not need to be discussed here but there 18 ovidence vilch suggests that oxidation occurs olower on the P1lmed specimens. This may be due to the presence of monoxide in the films formed in vacuum.
\end{abstract}

\title{
Orlentation of the Underlying Metal
}

Even with a cublc metal three mutually perpendicular planee do not belong to the eqme crystallographic family, in general. The planes (100), (010) and $(001)$ are perpendicular but in a more general case planes such as (211), (121) and (112) are not orthogonal to each other but do have common dihedral engles. In the case de an orthorhomblc metal, such as uranium, a G.oup of planes related by the permatation of their Niller Indices, ouch as the (211) group just mentioned, the planes do not have cormon alhedral angles. In addition, two mutually perpendicular planes, if perpendlcular to a third, ouch as say (101), will bear 11 ttie relation to each other in toras of thoir Miller indices. Therefore, the significance of the experiments to be described belon 15 that the (i10) dioxide texture vas formed on three mutually perpendicular surfaces of uranium, and that these surfaces did not have a common orientation which resulted from rolling the metal. Complex rolling textures are formed.

Study has established that the orlented oxide is forned with essentially no relation to the underlying wetal. Trangverse and long1 tudinal sections have been made of scose previously studied metal specimens. These were bolted together to present different opecimen surfaces and the oxide layers removed. When oxidizod as before, highly oriented dioxide films are formed vith the (110) plane of the oxide parallel to the specimen burface but without airectionality 
In that plane. The pertinent test data are presentod in rable $v$.

TABLE V

Orientation Risios and Test Conditions

\begin{tabular}{|c|c|c|c|c|}
\hline $\begin{array}{l}\text { Specimen } \\
\text { Mumber. }\end{array}$ & $\begin{array}{l}\text { Preliminary } \\
\text { Proatment }\end{array}$ & $\begin{array}{c}\text { Water } \\
\text { Preseure }\end{array}$ & $\begin{array}{l}\text { Ratio of } \\
\text { 2200/11I }\end{array}$ & $\frac{\text { Intense1tie:" }}{200 / 211}$ \\
\hline $\begin{array}{l}2130(W-6-z) \\
2151(W-6-8) \\
2132(W-5-8)\end{array}$ & $\begin{array}{l}\text { Electropollohed } \\
\text { Vec. anneal } \\
\text { Electropolish }\end{array}$ & $\begin{array}{l}\text { vacura } \\
28.4= \\
28.4\end{array}$ & $\begin{array}{l}1.0 \\
1.0 \\
1.80\end{array}$ & $\begin{array}{l}6.4 \\
0.50 \\
0.59\end{array}$ \\
\hline $\begin{array}{l}2133 \\
2134 \\
(W-4-I)\end{array}$ & $\begin{array}{l}\text { Electropolloh } \\
\text { Blectropolioh }\end{array}$ & $\begin{array}{l}17.0 \\
17.0\end{array}$ & $\begin{array}{l}28.2 \\
35.0\end{array}$ & $\begin{array}{l}1.47 \\
2.70\end{array}$ \\
\hline $\begin{array}{l}2135(W-4-E) \\
2135(W-7-E) \\
2136(W-7-E)\end{array}$ & $\begin{array}{l}\text { Front, electropolish } \\
\text { Beck, after mech. pol1sh } \\
\text { Blectropollsh }\end{array}$ & $\begin{array}{l}22.1 \\
22.1 \\
22.1\end{array}$ & $\begin{array}{l}2.4 \\
2.7 \\
6.4\end{array}$ & $\begin{array}{l}0.26 \\
0.27 \\
0.5\end{array}$ \\
\hline
\end{tabular}

"For random sasples $220 / 111$ is 0.49 and $200 / 111$ 1s 0.48 .

In run 2130 , the electropolished specimen was hestod in vacuum at $400^{\circ} \mathrm{C}$ for 90 minutes prior to oxidizing it in vater vapor. The orlentation appeare to be $(100)$ toxture, namely vith $(100) \mathrm{VO}_{2}$ planes parallel so the epectimen surface. Th1s orlentution has been astociated above vith monoxide formation. The simultaneous oxication of specinens 2130 and $\mathrm{W}-5-\mathrm{B}$ for 5 alnutes (to form 2131 and 2132) shows that in ap1to of a provious d1oxide orlentation, the (110) plenar dicxide orientation is fornod in vater vapor and apperently at the expense of the $(200)$ orientation.

Specimens 2133 and 2134 are transverse sections of rolled metal bolted together so that the rolling direction is perpendicular to the specinen ourface. Hence the (010) alpha planes were parallel to the speciman surface in contrast to the (102) alphe planes in ae-rolled abeet. Table $V$ shove that very atrong dioxide orlentations resulted from hesting at $400^{\circ} \mathrm{C}$ for 40 winuten.

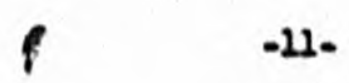




\section{1}

Data for pole f1gures vere obtalned. In both specimens, the (110) dioxide planes are parallel to the opecimen eurface but there is no evidence of directional orientation within this plane.

In the last group of experiments described in Tublo $\mathrm{V}$, longltudinal sectlons of rolled specimens vere employed. Thus the (102) alpha pianes were perpendicular to the opecimon exrface. Except for the beck of epecimen 2135, the (210)'dloxide plane vas found to be orlented parallel to the specinen surface. The beck side of electropolsabed specimens developo atite film wh1ch apparently is doxide with a slight preferred orientation. After oxidation in vater vapor, the (210) orlentation vas poorly aeveloped on. the back side, but a loose rust-colored oxide vas noticeable. After poliohing off this rust-colored material, the (110) orfentation was observable.

\section{Pole F1gures}

Several pole flgures have been constructed for specimens (zechanically pollshed) exposed in good vacuum st $600^{\circ} \mathrm{C}$. Here the motal 10 oxidized by the leakage gas. Both dioxide and monoxide are present in the film.

TABIS VI

Analyols of the Pole

F1gures for Vacuum Ireated Specimens

\begin{tabular}{|c|c|c|c|c|c|}
\hline $\begin{array}{l}\text { Specimen } \\
\text { number }\end{array}$ & $\begin{array}{l}\text { Duration } \\
\text { Hours }\end{array}$ & $\begin{array}{c}\text { Plane } \\
\text { Invest1 gated }\end{array}$ & $\begin{array}{l}\text { Plans } \\
\text { Parajlel }\end{array}$ & $\begin{array}{l}\text { Direction } \\
\text { In Plane }\end{array}$ & Remairks \\
\hline 1954 & 0.25 & $\begin{array}{l}(200) \mathrm{vO}_{2} \\
\text { (12I) } \mathrm{vO}_{2} \\
\text { (112) } a-v\end{array}$ & $\begin{array}{l}(100) \\
(100) \\
(102)\end{array}$ & $\begin{array}{l}\text { none } \\
\text { [010] }\end{array}$ & $\begin{array}{l}\text { slight orientation } \\
\text { also others }\end{array}$ \\
\hline 1953 & 16 & (12I) $\mathrm{JO}_{2}$ & (111) & none & \\
\hline 1955 & 168 & $\begin{array}{l}\text { (111) } v_{2} \\
\text { (121) } v_{0} \\
\text { (110) vo }\end{array}$ & $\begin{array}{r}\text { not }(110) \\
\text { silght } \\
\text { 811ght }\end{array}$ & $\begin{array}{l}\text { none } \\
- \\
-\end{array}$ & . \\
\hline
\end{tabular}


Specinen (1954) was exibsequently exposed to vater vapor at $600^{\circ} \mathrm{C}$. Pole Plgures constructed using the $(200)$ and $(210)$ planes of $\mathrm{UO}_{2}$ show that the 'U0) planes are parallel to the specimen surface. In the directions [001] and [II2] vithin the (110) plane of $\mathrm{VO}_{2}$, the intensities vere alightly higher but one aust conclude that there is essentiolly no directionality within the plane.

Specimens from several rums in vater vapor at $600^{\circ} \mathrm{C}$ vere also examined and thoir pole P1gures analyzed as shown below.

\section{TABLE VII}

Pole Figuri Analysis of Specimens Oxidized in Water Vapor

\begin{tabular}{|c|c|c|c|c|c|c|}
\hline $\begin{array}{l}\text { Specimen } \\
\text { number }\end{array}$ & $\begin{array}{l}\text { Pressure } \\
\mathrm{H}_{2} \mathrm{O}, \mathrm{m}\end{array}$ & Tgemp. & $\begin{array}{l}\text { Rat1o } \\
220 / 111\end{array}$ & $\begin{array}{c}\text { Plane } \\
\text { Invest1gated }\end{array}$ & $\begin{array}{l}\text { Plane } \\
\text { Perallel }\end{array}$ & $\begin{array}{l}\text { Direction } \\
\text { In Plane }\end{array}$ \\
\hline 1970 & 16.2 & 600 & 6.2 & $\begin{array}{l}\text { (110) } v_{2} \\
\text { (111) } v_{2}^{2} \\
(100) v_{2}\end{array}$ & $\begin{array}{l}(120) \\
(110) \\
(110)\end{array}$ & $\begin{array}{l}\text { none } \\
\text { sl1ght }[001] \\
\text { mod. }[001]\end{array}$ \\
\hline 1966 & 0.3 & 600 & 5.4 & (110) $\mathrm{vO}_{2}$ & (2120) & none \\
\hline 1975 & 1.3 & 300 & 5.6 & $(200) \mathrm{UO}_{2}$ & (120) & sllght [001] \\
\hline
\end{tabular}

The ovidence, although slight, suggests the preferred direction 1s [001] within the (110) plane of $\mathrm{UO}_{2}$.

Statistical analysis of the pole Plgure intensities has been made on two electropollehed specinens mentioned praviously. The orlentation "Index" as recommended by Professor Brick 1s. the standard deviation of Intensities above background divided by the gross average Intensity above beckground. Th1s index does not clearly differentiste between simple and complex textures, hovever where a simple texture is present, the index is 
usually higher. The pertinent data are:

\begin{tabular}{lllll} 
Specinen & Treatonent & Pressure & Index & Texture \\
\hline V-7-1 & $400^{\circ} \mathrm{c}, 0.25 \mathrm{hr}$ & $17 \mathrm{~m}$ & 0.386 & (110) $\mathrm{vo}_{2}$ \\
$\mathrm{H}-8-1$ & $400^{\circ} \mathrm{C}, 3 \mathrm{hr}$ & $6.9 \mathrm{~m}$ & 0.190 & (110) $\mathrm{vO}_{2}$
\end{tabular}

Theve orientation "indices" are compereble to those for rolled uranium. Although some directionality was present in the oxide it vas not sufficiently strong to justify assigning a definite orientation relationship between the oxide and the metal.

\section{Rate Iay}

Preliminary Investigation of rate law has been made. The consumption of water vapor releases hydrogen at $400^{\circ} \mathrm{C}$ and these $10 \mathrm{r}$ pressures and thus the reaction can be followed manometrically. After a few minutes at $400^{\circ} \mathrm{C}$, the reaction virtually ceases. The avellable data indicate that a logarithmic Lav is obeyed. 


\section{Rererences}

1. R. F. Nahl end E. L. McCandless, Mature 1341009 (1934); Nature, 137 702 (2934); Trans. AIVB, 125531 (2937).

2. E.A. Gulbransen A R. Ruka, Trans, Rlectrochen. Soc., 29360 (1952), Ind. Eng. Chem., 43697 (1951).

3. B. Lustmay and R. P. Mehl, Trans. AIVB, 1432.46 (2941).

4. c. K. Tucker, Trans. Amer. Boc. Netale, 42764 (1950).

5. C. W. Tucker, Acta Cryst., 6753 (2953)

6. J. J. Katz E. Rabinour1tch, "The Chemlstry of Uraniue" lat. Nucl. Ener. Serles VIII-5, 151.

7. 1b1a. 261

8. "Schultz Integrating RePlect1on Gonloseter", ASTE Tentative standards B49-86T, Revised 1954.

9. H. B. Svanson \& R. K. Fuyat, "Standard X-ray Diffraction Powder Patterns" IBS C1rcular 539, Vol. II (2954) 33.

10. c. 8. Barrett "Structure of Netals", NeGrav-H111, (New Yori 2943) p. $154 \mathrm{Pf}$. 